УДК 338.4

DOI: https://doi.org/10.26642/jen-2020-1(91)-55-59

І.І. Світлишин, к.е.н., доц.

Державний університет «Житомирська політехніка»

\title{
Результати діяльності підприємств сфери виробництва: аналітичний аспект
}

На основі системного підходу, використовуючи метод рядів динаміки проаналізовано результати діяльності підприємств сфери виробнищтва. Як основний індикатор застосовано обсяг реалізації продукції. Встановлено наявність деструкиії збалансованого розвитку сфери виробництва. 3 метою виключення впливу фактора кількості підприємств, досліджено обсяг реалізації продукиії у середньому одного підприємства за галузями сфери виробництва.

Для ідентифікації основних чинників, які впливають на формування результату діяльності підприємств сфери виробництва, як результативний показник застосовано обсяг реалізаціі продукиї з розрахунку на одного працівника підприємства. Дослідження проведено у розрізі великих, середніх $і$ малих підприємств за трьома групами галузей: сільського, лісового та рибного господарств; промисловості; будівництва. Використовуючи метод стохастичного факторного аналізу, встановлено, щуо основними чинниками формування результату діяльності підприємств сфери виробництва $\epsilon$ такі: рівень оплати праці персоналу, ступінь капіталоозброєності та матеріалоозброєності.

Враховуючи середовище функціонування підприємств сфери виробництвва, з'ясовано, щзо ияі чинники мають різні напрям і міру впливу на результативний показник у кожній галузі та для кожного виду підприємств. Використовуючи отримані в результаті дослідження рівняння регресії, запропоновано заходи щзодо покращення діяльності підприємств сфери виробництва в існуючому середовищі ведення бізнесу.

Ключові слова: підприємство; продукція; обсяг реалізації; оплата праці; капіталоозброєність; матеріалоозброєність.

Постановка проблеми. Сталий розвиток економіки країни, добробут ії населення, можливість зайняти належне місце серед країн Свропейського Співтовариства залежать, насамперед, від стану функціонування підприємств сфери виробництва, яка $\epsilon$ основою для розвитку інших сфер економіки країни. Трансформаційні процеси, які нині відбуваються у національній економіці, суттєво впливають на умови та чинники функціонування підприємств сфери виробництва. Як резонанс, змінюються результати діяльності підприємств інших галузей економіки, що в кінцевому підсумку формує рівень зайнятості населення, його фінансову спроможність і стабільність, значно впливає на свідомість і цінності кожного громадянина.

Виходячи із зазначеного, а також враховуючи наявні в країні ресурси, потужний, всебічно розвинений потенціал населення, вагомий досвід та існуючі технології виробництва, можливості для інвестиційної підтримки суб'єктів господарювання, проблема розвитку підприємств сфери виробництва $є$ не лише актуальною, а й однією з ключових як для науковців і практиків, так і для держави.

Аналіз останніх досліджень та публікацій. Дослідження стану, причин і тенденцій розвитку підприємств сфери виробництва досить широко висвітлені у наукових працях вчених $[2,3,8,10,11]$. Водночас висока динамічність середовища функціонування цих підприємств, наявність широкого спектра позицій науковців і практиків щодо їх подальшого розвитку і при цьому певна фрагментарність підходу не дають змоги ефективно та результативно реалізувати розроблені заходи.

Для забезпечення чіткого бачення стратегічних і тактичних трансформацій у сфері виробництва необхідним $\epsilon$, насамперед, 3'ясування всіх основних складових формування результату діяльності підприємств цієї сфери, взаємозв'язків між ними і ступеня їх впливу на кінцевий результат залежно від умов середовища функціонування.

Метою дослідження $\epsilon$ ідентифікація ключових складових формування результату діяльності підприємств сфери виробництва.

Викладення основного матеріалу дослідження. Досягнення поставленої мети передбачає окреслення видів підприємств сфери виробництва, визначення методичних прийомів та підходів до проведення дослідження, застосування відповідної системи індикаторів - показників.

Згідно з Національним класифікатором України до підприємств сфери виробництва належать такі: підприємства сільського, лісового та рибного господарств, підприємства добувної промисловості і розроблення кар'єрів, підприємства переробної промисловості, підприємства постачання електроенергії, газу, пари та кондиційованого повітря, підприємства водопостачання, каналізації та поводження 3 відходами і підприємства будівництва [9]. Для проведення дослідження зазначені підприємства об'єднано за функціональною ознакою у три групи: підприємства сільського, лісового та рибного господарств (секція А), промислові підприємства (секції В, C, D, Е) та підприємства будівництва (секція F). 
Методологічним підходом для проведення дослідження визначено системний, основними методичними прийомами $є$ аналіз рядів динаміки, стохастичний факторний аналіз та узагальнення.

Як індикатор результатів діяльності підприємств сфери виробництва застосовано обсяг реалізованої за певний період продукції у вартісному виразі - чистий дохід від реалізації продукції. Що є наслідком із зазначеного далі:

1. Функціональне призначення підприємств - це виробництво товарів;

2. Товар підприємства - це продукція, яка за своїми властивостям відповідає потребам споживачів і призначена для обміну (купівлі-продажу);

3. Ступінь задоволення потреб споживачів проявляється у ціні купівлі-продажу продукції $[1,6,7]$.

Згідно з даними Державної служби статистики України встановлено, що у 2017 р. загальний обсяг реалізації продукції підприємств сфери виробництва склав 3493,6 млрд грн, що у 2 рази більше від величини 2013 p. і у 2,6 раза - за рівень 2010 р. 3 чого випливає висновок про наявність позитивної тенденції зміни цього показника, при цьому темпи зростання останнього у розрізі зазначених періодів також мають позитивний вектор зміни.

Понад 80 \% величини досліджуваного показника забезпечили промислові підприємства, $13 \%$ підприємства сільського, лісового та рибного господарств і 6,3 \% - підприємства будівництва. Отже, спостерігається певна деструкція збалансованого розвитку сфери виробництва країни, виходячи із наявного ресурсного потенціалу, умов і факторів ведення бізнесу (табл. 1).

Обсяг реалізації продукції у середньому одного підприємства сфери виробництва суттєво різниться за групами підприємств. Так у великих підприємствах сільського, лісового та рибного господарств результативний показник у 2017 р. склав 2160 млн грн, що у 2,5 раза більше за рівень 2013 р. і у 2,4 раза - порівняно 32010 p. В аналогічних підприємствах будівництва показник дещо вищий і становить 2770,9 млн грн, або у 2,3 раза зріс проти 2013 р. і у 4,5 раза - проти 2010 р. Що ж до промислових підприємств, то значення досліджуваного показника у цій групі $є$ найбільшим і становить 7150,5 млн грн або у 2,9 раза перевищує рівень 2013 р. і у 3,3 раза - рівень 2010 р.

Динаміка обсягу реалізації продукиії підприємств сфери виробництва

Таблиия 1

\begin{tabular}{|l|c|c|c|c|c|}
\hline \multirow{2}{*}{ Вид підприємства } & \multicolumn{3}{|c|}{ Рік, млрд грн } & \multicolumn{2}{c|}{2017 р. до } \\
\cline { 2 - 6 } & 2010 p. & 2013 p. & 2017 p. & 2013 p. & 2010 p. \\
\hline Підприємства секції A & 99,9 & 161,1 & 454,4 & 2,8 раза & 4,5 раза \\
\hline Підприємства секцій B, C, D, E & 1159,2 & 1473,1 & 2817,8 & $191,3 \%$ & 2,4 раза \\
\hline Підприємства секції F & 96,7 & 141,1 & 221,4 & $156,9 \%$ & 2,3 раза \\
\hline Разом & 1355,8 & 1775,3 & 3493,6 & $196,8 \%$ & 2,6 раза \\
\hline
\end{tabular}

Джерело: сформовано автором за даними Державної служби статистики України

Подібна ситуація спостерігається і щодо середніх та малих підприємств сфери виробництва. Це підтверджує необхідність збалансування подальшого розвитку зазначеної сфери (табл. 2).

Таблиия 2

Динаміка обсягу реалізації продукиії у середньому одного підприємства сфери виробництва

\begin{tabular}{|l|c|c|c|c|c|}
\hline \multirow{2}{*}{ Вид підприємства } & \multicolumn{3}{|c|}{ Рік, млрд грн } & \multicolumn{2}{c|}{2017 р. до (разів) } \\
\cline { 2 - 6 } & 2010 p. & 2013 p. & 2017 p. & 2013 p. & 2010 p. \\
\hline Підприємства секції А - у середньому по групі & 2,0 & 3,2 & 9,1 & 2,8 & 4,6 \\
\hline У т. ч.: великі підприємства & 897,3 & 868,2 & 2160,0 & 2,5 & 2,4 \\
\hline середні підприємства & 19,1 & 30,5 & 99,9 & 3,3 & 5,2 \\
\hline малі підприємства & 0,5 & 1,0 & 3,7 & 3,6 & 7,7 \\
\hline Підприємства секцій В, С, D, Е - у середньому по групі & 24,2 & 30,0 & 67,0 & 2,2 & 2,8 \\
\hline У т. ч.: великі підприємства & 2147,0 & 2445,4 & 7150,5 & 2,9 & 3,3 \\
\hline середні підприємства & 59,0 & 82,9 & 230,1 & 2,8 & 3,9 \\
\hline малі підприємства & 1,3 & 1,8 & 5,1 & 2,8 & 3,9 \\
\hline Підприємства секції F -у середньому по групі & 2,5 & 3,9 & 8,1 & 2,1 & 3,2 \\
\hline У т. ч.: великі підприємства & 621,1 & 1210,1 & 2770,9 & 2,3 & 4,5 \\
\hline середні підприємства & 36,0 & 57,3 & 126,5 & 2,2 & 3,5 \\
\hline малі підприємства & 1,0 & 1,6 & 4,1 & 2,6 & 4,1 \\
\hline
\end{tabular}

Джерело: сформовано автором за даними Державної служби статистики України 
Оскільки ключовим чинником успішного функціонування підприємств сфери виробництва є їхній персонал, який застосовуючи набуті компетентності, інноваційне мислення та існуючі ресурси фактично створює конкурентоздатну, якісну продукцію, дослідження формування результату діяльності підприємства здійснено за показником - обсяг реалізації продукції у середньому на одного працівника підприємства (табл. 3).

Таблиия 3

Динаміка обсягу реалізації продукиї̈ у середньому на одного працівника підприємства сфери виробництвва

\begin{tabular}{|l|c|c|c|c|c|}
\hline \multirow{2}{*}{ Вид підприємства } & \multicolumn{3}{|c|}{ Рік, тис. грн } & \multicolumn{2}{c|}{2017 р. до (разів) } \\
\cline { 2 - 6 } & 2010 p. & 2013 p. & 2017 p. & 2013 p. & 2010 p. \\
\hline Підприємства секції А - у середньому по групі & 130,0 & 234,5 & 766,2 & 3,3 & 5,9 \\
\hline У т. ч.: великі підприємства & 354,5 & 604,1 & 1413,8 & 2,3 & 4,0 \\
\hline середні підприємства & 127,2 & 216,9 & 708,7 & 3,3 & 5,6 \\
\hline малі підприємства & 103,1 & 204,6 & 772,8 & 3,8 & 7,5 \\
\hline Підприємства секцій В, С, D, Е - у середньому по групі & 374,9 & 503,6 & 1309,6 & 2,6 & 3,5 \\
\hline У т. ч.: великі підприємства & 531,4 & 683,4 & 2067,7 & 3,0 & 3,9 \\
\hline середні підприємства & 270,9 & 380,7 & 980,5 & 2,6 & 3,6 \\
\hline малі підприємства & 150,0 & 223,5 & 640,0 & 2,9 & 4,3 \\
\hline Підприємства секції F - у середньому по групі & 204,9 & 379,7 & 865,5 & 2,3 & 4,2 \\
\hline У т. ч.: великі підприємства & 477,8 & 1527,3 & 4105,0 & 2,7 & 8,6 \\
\hline середні підприємства & 257,9 & 420,7 & 967,5 & 2,3 & 3,8 \\
\hline малі підприємства & 146,4 & 284,7 & 736,7 & 2,6 & 5,0 \\
\hline
\end{tabular}

Джерело: сформовано автором за даними Державної служби статистики України

3 даних таблиці 3 зрозуміло, що обсяг реалізації продукції у середньому на одного працівника у всіх трьох групах підприємств сфери виробництва характеризується позитивною тенденцією зміни. При цьому в промислових підприємствах він має найвище значення і становить у 2017 р. 1309,6 тис. грн, коли в підприємствах будівництва - 865,5 тис. грн, а у підприємствах сільського, лісового та рибного господарств - 766,2 тис. грн.

У розрізі видів підприємств спостерігається дещо інша ситуація стосовно величини результативного показника. Так серед великих підприємств найвище значення показника у галузі будівництва4105 тис. грн, а найменше значення у галузях сільського, лісового та рибного господарств - 1413,8 тис. грн. Серед малих підприємств найвище значення показника у галузях сільського, лісового та рибного господарств - 772,8 тис. грн, а найменше значення у промислових галузях - 640 тис. грн. 3 огляду на це, стохастичний факторний аналіз результативного показника проведено окремо по кожній групі і кожному виду підприємств (табл. 4).

Таблиия 4

Результати стохастичного факторного аналізу обсягу реалізації продукиії у середньому на одного працівника підприємства сфери виробництва

\begin{tabular}{|c|c|c|}
\hline Вид підприємства & Рівняння регресії & $\begin{array}{c}\text { Коефіцієнт } \\
\text { детермінації }\left(\mathrm{r}^{2}\right)\end{array}$ \\
\hline \multicolumn{3}{|l|}{ Підприємства секції А: } \\
\hline великі підприємства & $y=378,7+2,7 x 1-2,79 x 2+1,59 x 3$ & 0,8798 \\
\hline середні підприємства & $y=16,1+5,33 \times 1-3,42 \times 2+2,5 \times 3$ & 0,9979 \\
\hline малі підприємства & $y=-108,3+6,23 \times 1-0,66 \times 2+1,96 \times 3$ & 0,9995 \\
\hline \multicolumn{3}{|c|}{ Підприємства секцій В, C, D, E: } \\
\hline великі підприємства & $\mathrm{y}=-310,3+6,68 \mathrm{x} 1+0,52 \mathrm{x} 2+0,91 \mathrm{x} 3$ & 0,9999 \\
\hline середні підприємства & $y=-100,6+6,43 \times 1+0,66 \times 2+0,96 \times 3$ & 0,9918 \\
\hline малі підприємства & $y=-43,9+0,92 \times 1+0,2 \times 2+1,53 \times 3$ & 0,9992 \\
\hline \multicolumn{3}{|l|}{ Підприємства секції F: } \\
\hline великі підприємства & $y=436,5+0,12 x 1+15,65 \times 2-0,07 x 3$ & 0,7868 \\
\hline середні підприємства & $y=28,6+5,13 \times 1-0,26 \times 2+0,84 \times 3$ & 0,9989 \\
\hline малі підприємства & $y=-257,7+7,09 \times 1+2,05 \times 2+0,65 \times 3$ & 0,9973 \\
\hline
\end{tabular}

Примітка: у - чистий дохід (виручка) від реалізації продукції з розрахунку на одного працівника підприємства сфери виробництва; х1 - рівень оплати праці персоналу; х2 - ступінь капіталоозброєності; х3 - ступінь матеріалоозброєності.

Джерело: результати досліджень автора 
Дані таблиці 4 свідчать, що результати діяльності підприємств сфери виробництва формуються під впливом переважно трьох факторів: рівня оплати праці персоналу, капіталоозброєності та матеріалоозброєності. При цьому напрям впливу цих факторів на результативний показник різний.

У підприємствах сільського, лісового та рибного господарств для покращення результатів діяльності головну увагу слід зосередити на оплаті праці персоналу: збільшення значення цього фактора на 1 тис. грн призведе до зростання чистого доходу (виручки) від реалізації продукції з розрахунку на одного працівника на 2,7 тис. грн у великих підприємствах, на 5,33 тис. грн - у середніх підприємствах, на 6,23 тис. грн - у малих підприємствах. Крім того, потрібно докорінно змінити політику оновлення основного капіталу, оскільки підвищення капіталоозброєності на 1 тис. грн за існуючого підходу призведе до зменшення чистого доходу (виручки) від реалізації продукції з розрахунку на одного працівника на 2,79 тис. грн у великих підприємствах, на 3,42 тис. грн - у середніх підприємствах, на 0,66 тис. грн - у малих підприємствах.

У промислових підприємствах для покращення результатів діяльності доцільно збільшувати значення всіх трьох факторів. Водночас у великих і середніх підприємствах суттєво впливає на результативний показник фактор оплати праці: збільшення значення цього фактора на 1 тис. грн призведе до зростання результативного показника на 6,68 тис. грн у великих підприємствах i на 6,43 тис. грн - у середніх підприємствах. У малих промислових підприємствах ключовим є фактор матеріалоозброєності: підвищення його значення на 1 тис. грн призведе до збільшення результативного показника на 1,53 тис. грн.

Щодо підприємств будівництва, то для покращення результатів їхньої діяльності варто зосередити зусилля на таких факторах:

- у великих підприємствах - на капіталоозброєності (підвищення значення цього фактора на 1 тис. грн призведе до зростання результативного показника на 15,65 тис. грн) та матеріалоозброєності (змінити постачальників сировини та матеріалів, оскільки вплив цього фактора на результативний показник $\epsilon$ негативним: підвищення ступеня матеріалоозброєності на 1 тис. грн призведе до зменшення результативного показника на 0,07 тис. грн);

- у середніх підприємствах - на оплаті праці персоналу (підвищення значення цього фактора на 1 тис. грн призведе до зростання результативного показника на 5,13 тис. грн.) та капіталоозброєності (змінити політику оновлення основного капіталу: підвищення значення цього фактора на 1 тис. грн призведе до зменшення результативного показника на 0,26 тис. грн);

- у малих підприємствах - на всіх трьох факторах шляхом збільшення їх значення: збільшення рівня оплати праці на 1 тис. грн призведе до зростання результативного показника на 7,09 тис. грн; підвищення ступеня капіталоозброєності на 1 тис. грн призведе до зростання результативного показника на 2,05 тис. грн; підвищення ступеня матеріалоозброєності на 1 тис. грн призведе до зростання результативного показника на 0,65 тис. грн.

Висновки. Сфера виробництва $є$ основою для розвитку всіх інших сфер національної економіки. Нині спостерігається певна деструкція збалансованого розвитку цієї сфери. Незважаючи на позитивну тенденцію зміни основного узагальнюючого показника результатів діяльності підприємств сфери виробництва, вона має проблеми, які потребують невідкладного вирішення. Ключовими чинниками поліпшення результатів діяльності підприємств сфери виробництва $є$ рівень оплати праці персоналу, ступінь капіталоозброєності та матеріалоозброєності. Проте вплив цих чинників на результати діяльності підприємств у кожній групі різний, що вимагає найповнішого врахування специфіки кожного підприємства.

\section{Список використаної літератури:}

1. Арич M.I. Концептуальні підходи до визначення фінансово-економічних результатів підприємства / M.I. Арич // Економіка та держава. - 2013. - № 7. - С. 66-69.

2. Гречан А.П. Діагностика ефективності діяльності підприємств. / А.П. Гречан, Н.Й. Радіонова [Електронний pecypc] - Режим доступу : http://www.nbuv.gov.ua/portal/soc_gum/vsunu/2011_10_1/Grechina.pdf.

3. Дікань Л.В. Фінансовий результат підприємств: теоретичні узагальнення та прикладний аналіз : монографія. / Л.В. Дікань, О.О. Вороніна. - Х. : СПД ФО Лібуркіна Л.М., 2008. - 92 с.

4. Діяльність суб’єктів великого, середнього, малого та мікропідприємництва за 2017 р. : статистичний збірник / відп. О.Колпакова. - К. : Державна служба статистики України, 2018. - 343 с.

5. Діяльність суб'єктів господарювання за 2017 р. : статистичний збірник / відп. О.Колпакова. - К. : Державна служба статистики України, 2018. - 145 с.

6. Економічна теорія: Політекономія : підручник / за ред. В.Д. Базилевича. - 6-те вид., перероб. і доп. К. : Знання-Прес, 2007. - 719 с.

7. Козак В.С. Економічні результати як елементи оцінки діяльності підприємства. / В.С. Козак, Г.О. Христич // Вісник Хмельницького національного університету. - 2009. - № 6. - С. 7-11. 
8. Малюта Л.Я. Збитковість підприємств - загроза економічній безпеці держави. (Постконфліктні причини гальмування розвитку підприємств машинобудівної галузі) / Л.Я. Малюта // Теоретичні і практичні аспекти економіки та інтелектуальної власності. - 2015. - Вип. 2 (12). - С. 140-147.

9. Національний класифікатор України: Класифікація видів економічної діяльності ДК 009-96 [Електронний pecypc]. - Режим доступу : https://zakon.rada.gov.ua/rada/show/vb457609-10.

10. Оцінка економічних результатів діяльності підприємств корпоративного типу : монографія / В.Я. Нусінов, С.П. Лобов, О.М. Жовна, Я.В. Нусінова. - Кривий Ріг, 2012. - 270 с.

11. Турило А.А. Оцінка результативності, ефективності, продуктивності і збитковості підприємства : монографія / А.А Турило, А.М. Турило. - Кривий Ріг : Етюд-Сервіс, 2009. - 196 с.

\section{References:}

1. Arych, M.I. (2013), «Kontseptual'ni pidkhody do vyznachennya finansovo-ekonomichnykh rezul'tativ pidpryyemstva», Ekonomika ta derzhava, No. 7, pp. 66-69.

2. Hrechan, A.P. (2011), «Diahnostyka efektyvnosti diyal'nosti pidpryyemstv», [Online], available at: http://www.nbuv.gov.ua/portal/soc_gum/vsunu/2011_10_1/Grechina.pdf

3. Dikan', L.V. (2008), Finansovyy rezul'tat pidpryyemstv: teoretychni uzahal'nennya ta prykladnyy analiz, monohrafiya, SPD FO Liburkina L.M, Kharkiv, 92 p.

4. Diyal'nist' subyektiv velykoho, seredn'oho, maloho ta mikropidpryyemnytstva za 2017 r. (2018), statystychnyy zbirnyk, vidpov. O.Kolpakova, Kyiv, 343 p.

5. Diyal'nist' subyektiv hospodaryuvannya za 2017 r. (2018)., statystychnyy zbirnyk, vidpov. O.Kolpakova, Kyiv, 145 p.

6. Bazylevych, V.D. (ed.) (2007), Ekonomichna teoriya: Politekonomiya, pidruchnyk, Kyiv, 719 p.

7. Kozak, V.Je. (2009), «Ekonomichni rezul'taty yak elementy otsinky diyal'nosti pidpryyemstva», Visnyk Khmel'nyts'koho natsional'noho universytetu, No. 6, pp. 7-11.

8. Malyuta, L.Ja. (2015), «Zbytkovist' pidpryyemstv - zahroza ekonomichniy bezpetsi derzhavy. (Postkonfliktni prychyny hal'muvannya rozvytku pidpryyemstv mashynobudivnoyi haluzi)», Teoretychni i praktychni aspekty ekonomiky ta intelektual'noyi vlasnosti, Issue 2 (12), pp. 140-147.

9. Natsional'nyy klasyfikator Ukrayiny: klasyfikatsiya vydiv ekonomichnoyi diyal'nosti DK 009-96, [Online], available at: https://zakon.rada.gov.ua/rada/show/vb457609-10

10. Nusinov, V.Ja., Lobov, S.P., Zhovna, O.M. and Nusinova, Ja.V. (2012), Otsinka ekonomichnykh rezul'tativ diyal'nosti pidpryyemstv korporatyvnoho typu, monohrafiy», Kryvyj Rih, 270 p.

11. Turylo, A.A. (2009), Otsinka rezul'tatyvnosti, efektyvnosti, produktyvnosti i zbytkovosti pidpryyemstva, monohrafiya, Etyud-Servis, Kryvyj Rih, 196 p.

Світлишин Ігор Іванович - кандидат економічних наук, доцент кафедри менеджменту i підприємництва Державного університету «Житомирська політехніка».

Наукові інтереси:

- проблеми ефективності функціонування підприємств. 